Available online at: http://e-journal.upstegal.ac.id/index.php/jip

Submit : 25-07-2017; Revision: 29-o8-2017; Publish: 30-10-2017

\title{
POLITIK PEMBERDAYAAN PETANI DI DESA RAMBAH MUDA, RIAU
}

\author{
Khairul Anwar1) *, Meyzi Hariyanto2) \\ 1,2Program Studi Ilmu Pemerintahan, Universitas Riau. Kampus Bina Widya KM12.5. Simpang \\ Baru, Tampan, Kota Pekanbaru, Riau. \\ * Korespondensi Penulis. E-mail:khairulanwar147@yahoo.com
}

\begin{abstract}
Abstrak
Penelitian ini bertujuan untuk mengembangkan model dan strategi politik-ekonomi berbasis masyarakat melalui pengorganisasian petani dengan mengambil contoh sistem integrasi sapi-kelapa (Siska) di Desa Rambah Muda. Dalam jangka pendek riset ini bertujuan untuk mengidentifikasi masalah model kelembagaan petani dalam rangka pengelolaan konflik kelapa sawit. Metode yang digunakan untuk mencapai tujuan tersebut dengan mengidentifikasi: (1) pelaku terkait pelaksanaan Siska di Desa Rambah Muda; (2) Tujuan dan kepentingan aktor; (3) Basis sosial dan kelembagaan petani; (4) Jaringan sosio-ekonomi petani pola swadaya. Target khusus hasil penelitian tahun pertama ini adalah: strategi pemberdayaan petani kelapa sawit. Hasil penelitian menunjukkan bahwa pengaturan kelembagaan petani di era reformasi tidak dimulai dari kepentingan petani. Dinamika penataan melibatkan banyak aktor dengan kepentingan yang saling tumpang tindih dan basis sosial yang beragam. Ada kecenderungan strategi penataan yang berfokus pada pemberdayaan petani untuk mendorong kerja lembaga petani yang lebih terintegrasi.

Kata Kunci: Politik Pemberdayaan, Ekonomi Petani, Sistem Integrasi
\end{abstract}

\section{POLITICS OF FARMER EMPOWERMENT IN THE VILLAGE OF YOUNG RAMBAH, RIAU}

\begin{abstract}
This research is aimed at developing a model and strategy of acceleration of sustainable community-based economic development through self-organization of self-help farmers by taking the example of a system of cattle-palm oil (Siska) integration in Rambah Muda Village. In the short term this research aims to find the model of institutional breakthrough of farmers in the context of managing oil palm conflicts. The method used in achieving that goal by identifying: (1) the actors related to the implementation of Siska in Rambah Muda Village; (2) The aims and interests of the actor; (3) The social and institutional basis of farmers; (4) Socio-economic network of farmers selfhelp pattern. Specific target of this first year research result is: empowerment strategy of palm oil farmer. The results showed that the institutional arrangement of peasants in the reform era started from farmers. The dynamic of structuring involves many actors with conflicting interests and diverse social bases. There is a tendency for a structuring strategy that focuses on empowering farmers to encourage the working of more integrated peasant institutions.
\end{abstract}

Keywords: Political Empowerment, Farmer's economy, system integration 


\section{Jurnal Ilmu Pemerintahan, 2 (2), Oktober 2017 - 104}

Khairul Anwar , dan Meizy Haryanto

\section{PENDAHULUAN}

Kebijakan Otonomi Daerah (Otda) di Indonesia menimbulkan perdebatan mengenai siapa sesungguhnya yang bertanggungjawab atas kesejahteraan masyarakat di Daerah.1 Undang-Undang Nomor 23 Tahun 2014 tentang Pemerintahan Daerah menjelaskan bahwa Daerah kabupaten yang merupakan daerah otonom memiliki hak dan kewajiban dalam menyejahterakan masyarakat dengan caranya sendiri. Pada masa pasca Otda Indonesia termasuk di Riau khusunya Kabupaten Rokan Hulu menghadapi permasalahan besar yaitu pesatnya pertumbuhan perkebunan kelapa sawit, tetapi tidak diimbangi pola pemanfaatan lahan secara optimal, inefisiensi distribusi pupuk ke petani, dan pelembagaan manajemen konflik sosial. Beberapa riset Casson (2000), Syahza (2013), Anwar (2014 ) , dan Isril (2015) menunjukkan bahwa konflik kepentingan kelembagaan antara petani, pelaku bisnis dan Pemerintah (lokal) era pasca Orde Baru (Orba) intensitanya semakin tinggi dan dampaknya melemahkan ekonomi masyarakat terutama petani swadaya. Dalam kondisi seperti ini, muncul kebijakan Pemerintah untuk memenuhi 90\% pangan asal ternak melalui program Siska dan program replanting perkebunan. Berbagai program ini merupakan tantangan sekaligus peluang

\footnotetext{
${ }^{1}$ Undang-Undang Nomor 23 Tahun 2014 tentang Pemerintahan Daerah menjelaskan bahwa Daerah Kabupaten yang merupakan daerah otonom memiliki hak dan kewajiban dalam mensejahterakan masyarakat dengan caranya sendiri. Salah satu urusan wajib bagi Pemerintahan Daerah adalah menjaga ketahanan pangan meliputi :Revitalisasi Pertanian, Peternakan, Perkebunan,Perikanan,dan Kehutanan secara terintegrasi.
}

bagi masyarakat lokal terutama petani swadaya.

Persoalan pemberdayaan petani ini telah memunculkan pertanyaan ekonomipolitik lokal yang menarik untuk diamati lebih dalam dan inilah yang mendorong peneliti untuk mempelajari strategi pemberdayaan petani konteks percepatan pembangunan ekonomi di Riau. Dengan tuntunan literatur ekonomipolitik Freeden (2000), peneliti berusaha mengidentifikasi kelembagaan, kepentingan, preferensi aktor, pemberdayaan, dan interaksi aktor dengan lembaga informal lainnya. Selama ini sepengetahuan peneliti belum ada penelitian politik yang menggunakan isu kebijakan Siska dan perkebunan kelapa sawit sebagai pintu masuk dalam mendapatkan informasi ilmiah terkait kelembagaan dan pemberdayaan paling tidak konteks Riau. Penulis berharap agar hasil penelitian ini akan mempunyai arti dalam mengisi kekosongan kajian politik lokal dalam konteks percepatan dan perluasan pembangunan ekonomi Indonesia 2011-2025. Untuk lebih memudahkan memahami fenomena pemberdayaan,konseptualisasi fenomena ini dapat diketahui dari berbagai riset dibawah ini.

Dalam skala makro Rozaki (2016) melakukan penelitian bahwa pengalaman banyak Desa di Indonessia selama ini memiliki pelajaran berharga (lesson learned) dalam membangun kemandirian berbasis potensi lokal melalui proses berjejaring dan persenyawaan program (engagement) dengan Lembaga Swadaya Masyarakat (LSM), Perguruan Tinggi (PT), program CSR dan aktor penggerak perubah lainnya sangat layak diakomodasi dan memperoleh tindakan 
afirmatif dari Kementerian Desa Tertinggal (PDT) terutama yang dilakukan para aktor diluar negara (non state actor),seperti para LSM di daerah pasca reformasi yang memiliki berbagai program dan pendekatan didalam melakukan pemberdayaan masyarakat.

Selaras riset Rozaki (2016), riset yang dilakukan Sulistyani layak digunakan mempertajam konsep pem- berdayaan masyarakat terutama petani Menurut Sulistyani (2017) dalam rangka pemberdayaan masyarakat miskin (petani) perlu dirancang kontribusi masing-masing aktor, yaitu pemerintah, swasta dan masyarakat sehingga terbentuk model kemitraan yang diharapkan. Rancangan peran ketiga aktor tersebut tampak pada tabel berikut ini:

Tabel.1.Peran Tiga Aktor Dalam Pemberdayaan Masyarakat

\begin{tabular}{|c|c|c|c|}
\hline Aktor & $\begin{array}{c}\text { Peran Dalam } \\
\text { Pemberdayaan }\end{array}$ & Bentuk Output Peran & Fasilitasi \\
\hline Pemerintah & $\begin{array}{l}\text { Formulasi dan } \\
\text { Penetapan } \\
\text { kebijakan } \\
\text { Implementasi } \\
\text { Monitoring dan } \\
\text { Evaluasi } \\
\text { Mediasi }\end{array}$ & $\begin{array}{l}\text { Kebijkan Politik, Umum, } \\
\text { Khusus/Departemental/Sektoral } \\
\text { Penganggaran, Juknis dan Juklak, } \\
\text { Penetapan indikator } \\
\text { keberhasilan.Peraturan } \\
\text { hukum, penyelesaian sengketa }\end{array}$ & $\begin{array}{l}\text { Dana, } \\
\text { Jaminan, Alat, } \\
\text { Teknologi, } \\
\text { Jaringan, Sistem } \\
\text { manajemen } \\
\text { informasi, } \\
\text { Edukasi }\end{array}$ \\
\hline Swasta & $\begin{array}{l}\text { Kontribusi pada } \\
\text { formulasi, } \\
\text { Implementasi, } \\
\text { Monitoring dan } \\
\text { Evaluasi }\end{array}$ & $\begin{array}{l}\text { Konsultasi \& rekomendasi } \\
\text { kebijakan, tindakan dan langkah } \\
\text { implementasi, donator, private } \\
\text { investment pemeliharaan }\end{array}$ & $\begin{array}{l}\text { Dana, Alat, } \\
\text { Teknologi, } \\
\text { Tenaga ahli dan } \\
\text { sangat } \\
\text { terampil }\end{array}$ \\
\hline Masyarakat & $\begin{array}{l}\text { Partisipasi } \\
\text { dalam } \\
\text { formulasi, } \\
\text { Implementasi, } \\
\text { Monitoring dan } \\
\text { Evaluasi }\end{array}$ & $\begin{array}{l}\text { Saran, Input, Kritik, } \\
\text { Rekomendasi, } \\
\text { Keberatan dukungan dalam } \\
\text { formulasi kebijakan. } \\
\text { Implementasi, Dana Swadaya } \\
\text { Menjadi Objek, Partisipan, } \\
\text { Pelaku utama/subjek. } \\
\text { Menghindupkan fungsi } \\
\text { pengawasan sosial. }\end{array}$ & $\begin{array}{l}\text { Tenaga terdidik, } \\
\text { Tenaga terlatif, } \\
\text { Setengah } \\
\text { terdidik dan } \\
\text { Setengah } \\
\text { terlatih }\end{array}$ \\
\hline
\end{tabular}

Sumber: Sulistyani,2017:97-98

Masih menurut Sulistiyani bahwa berdasarkan pemetaan tiga aktor dalam tabel di atas, pemerintah lebih banyak berperan pada penentuan rambu-rambu dan aturan main secara umum.Peran pemerintah yang paling menonjol sesungguhnya terletak pada peran pengambilan keputusan dan pendanaan.Namun mengingat adanya kemungkinan terjadi sengketa di dalam perjalanan pembangunan tersebut maka diperlukan peran mediasi terutama untuk mengontrol peran swasta supaya berjalan wajar tidak merugikan 
masyarakat.Selanjutnya,

swasta

mempunyai peran lebih banyak pada implementasi per-aturan langkah bersama masyarakat. Peran swasta dalam implementasi kebijakan pemberdayaan masyarakat juga mencakup kontribusi dana melalui investasi swasta yang bermanfaat untuk mendukung proses pemberdayaan masyarakat. Selanjutnya, Sulistiayani menjelaskan bahwa peran masyarakat dalam konteks pemberdayaan diberikan dalam bentuk partisipaasi baik pada level komunitas, implementasi, monitoring maupun evaluasi. Tinggi rendahnya partisipasi yang diberikan akan berdasar-kan pada tingkat keberdayaan yang dilimiki oleh masyarakat,dan kemampuan pemahaman pada setiap level dalam proses kebijakan publik.

Di Riau, tingkat keberdaayaan sesuai dengan bentuk kegiatan ekonomi masyarakat. Menurut Mubyarto (1995) bentuk ekonomi masyarakat Riau terbagi kepada tiga subsistem, yaitu: subsitem ekonomi modern sepertii perkebunan besar, subsistem ekonomi tradisional agraris tradisional seperti perkebunan kecil, dan subsistem ekonomi penduduk asli Riau daratan seperti orang sakai, talang mamak, suku laut. Masyarakat dalam subsistem ekonomi modern tingkat keberdayaan ekonomi jauh lebih baik daripada kelompok masyarakat dalam subsistem ekonomi tradisional. Dalam kondisi seperti itu, di Riau terjadi pertumbuhan yang tidak seimbang antara perkebunan besar kelapa sawit dengan perkebunan kelapa sawit rakyat.

Dalam kaitan dengan revitalisasi perternakan, menurut Daryanto (2017) dapat dilihat dalam dua aras yaitu: aras makro yang memfokuskan pada domain aturan main. Peraturan perundangan ini pada dasarnya akan mempengaruhi tatanan perilaku dan kinerja dari para pelaku yang terlibat dalam proses transaksi aras mikro yang lebih memfokuskan pada institusional arrangement, sebagai upaya mengatur antar unit sosialekonomi mengenai cara-cara bekerjasama dan berkompetisi di antara anggotanya dalam mencapai tujuan.

Selanjutnya Daryanto menjelaskan bahwa pemahaman akan makna institusi ini menjadi penting artinya karena aktivitas di ektor peternakan baik dalam produksi,distribusi dan konsumsi melibatkan banyak pihak yang mempunyai kepentingan. Kendala yang sering dijumpai (pemberdayaan) di sektor peternakan adalah upaya untuk mengakomodasikan berbagai kepentingan yang seringkali bertentangan satu dengan yang lainnya. Salah satu kunci sukses keberhasilan program revitalisasi pembangunan peternakan terletak sejauh mana kita akan melakukan penguatan kelembagaan.

Selaras dengan penelitian di atas, Elizabeth (2007) melakukan riset penguatan dan pemberdayaan kelembagaan petani mendukung pengembangan agribisnis kedelai. Menurut Elizabeth lembaga di perdesaan lahir untuk memenuhi kebutuhan sosial masyarakatnya.Sifatnya tidak linier, namun cenderung merupakan kebutuhan individu anggotanya, berupa kebutuhan fisik, kebutuhan rasa aman, kebutuhan hubungan sosial, pengakuan dan pengembangan. Manfaat utama lembaga adalah mewadahi kebutuhan salah satu sisi kehidupan sosial masyarakat, dan sebagai pengawasan sosial. Setiap orang 
dapat mengatur perilakunya menurut kehendak masyarakat.

Lebih jauh Elizabet (2007) menjelaskan bahwa lembaga yang ada sekarang berkembang di pedesaan merupakan lembaga modern, karena umumnya telah memiliki: truktur dan tata nilai yang jelas, telah diformalkan (dengan terdapatnya kepastian anggota, proses pelaksanaan), adanya aturan tertulis dalam anggaran dasar dan rumah tangga ,dan adanya kepemimpinan yang resmi, dan biasanya sengaja dibentuk karena tumbuhnya kesadaran pentingnya keberadaan lembaga tersebut.

Selaras dengan penelitian Elizabet, Eko (2013) meneliti pembangunan dan kesejahteraan di pedesaan. Menurut Sutoro bahwa inkulisifitas daerah banyak ditentukan oleh proses pelembagaan dan pemberdayaan masyarakat pedesaan. Demikian pula, Tohari (2013) menunjukkan bahwa perangkap demokrasi populer dan liberal memang tidak memikirkan persoalan kesejahteraan. Karena itu kita harus keluar dari perangkap demokrasi minimalis tersebut dan melakukan pemberdayaan, basis empiris masyarakat argraris terletak pada penguasaan tanah dan ternyata konflik penguasaan tanah memiliki kaitan erat dengan kelembagaan demokrasi.

Berbagai riset yang diuraikan dalam pembahasan sebelumnya pada dasarnya memfokuskan diri pada isu pemberdayaan pembangunan ekonomi dan kebijakan perkebunan. Tulisan ini fokusnya pada strategi pemberdayaan di tingkat lokal yang menggunakan isu kebijakan Siska yang diterapkan di kebun swadaya sebagai pintu masuk. Studi mengenai pemberdayaan petani selama ini tidak mengkaitkannya dengan per- soalan politik lokal. Konseptualisasi yang diajukan para kaum pluralis uraian sebelumnya sudah dikualifikasi oleh teori "group politics", dan "local politics" dan bisa dipakai untuk merumuskan kerangka teoritik pemberdayaan petani swadaya pola Siska di Riau.

\section{METODE}

Metode yang digunakan dalam peneltian ini adalah: Pertama, melakukan identifikasi berbagai faktor, unsur penentu pembangunan wilayah dan institusi perkebunan di Desa rambah Muda melalui teknik analisis SWOT, strength (kekuatan), weaknesses (kelemahan), opportunities (peluang) dan therat (ancaman). Kedua, melalui teknik analisis Modern Political Economy melakukan identifikasi: (1) Tujuan.dan preferensi aktor terkait implementasi kebijakan Siska di Desa rambah Muda; (2) Karakteristik sosial- sumberdaya kelompok tani; (3) Sarana dan prasarana kelompok tani Siska; (4) Basis insitusi dan kebijakan terkait program Siska.

Dipilihnya Desa Rambah Muda, kecamatan Rambah Hilir Kabupaten Rakona Hulu dengan beberapa pertimbangan. Pertama, Desa Rambah Muda adalah tempat yang memiliki kelompok tani yang paling dinamik di Rokan Hulu. Kedua, sehingga desa Rambah Muda dapat dijadikan tempat yang efektif untuk melihat implementasi berbagai regulasi yang dibuat pemkab Rohul terkait pegternakan misalnya Peraturan Bupati Rokan Hulu No. 21 Tahun 2012 tentang Pola Pengembalian Gaduhan Ternak di Kabupaten Rokan Hulu, Peraturan Bupati Rokan Hulu No. 45 Tahun 2012 tentang Rencana Aksi Daerah Percepatan Pencapaian Target Millenium Development Goals Tahun 
2012-2015, Peraturan Bupati Rokan Hulu Nomor 71 Tahun 2011 tentang Uraian Tugas dan Tata Kerja Jabatan Struktural Pada Dinas Perikanan dan Peternakan Kabupaten Rokan Hulu, Surat Keputusan Kepala Dinas Perikanan dan Peternakan Kabupaten Rokan Hulu tentang Penunjukan Petugas Pembimbing Bibit Sapi Tahun 2015.Data dikumpul melalui observasi, wawancara dan dokumentasi.Wawancara dilakukan terhadap paratur Pemkab Rokan Hulu, pihak Dewan Perwakilan Rakyat Daerah (DPRD), ketua dan anggota kelompok Tani.

Data yang dikumpul selanjutnya dianalisis dengan menggunakan pendekatan Modern Political Economy yangmemuat empat langkah seperti yang dijelaskan Frieden (2000) yaitu: Pertama, mengidentifikasi para aktor konteks implementasi kebijakan pola Siska di Rambah Muda, dan menentukan apa yang menjadi tujuan dan kepentingannya. Aktor-aktor tersebut berasal dari kalangan birokrasi maupun masyarakat petani. Kedua, menggambarkan proses preferensi masing-masing aktor mengenai kebijakan perkebunan kelapa sawit dan Siska yang diterapkan Ketiga, mendiskripsikan bagaimana para aktor mengorganisir diri dalam mencapai tujuan produktivitas. Pengorganisasian ini dilakukan dalam rangka memperkuat daya tawar terhadap kelompok lain dan Pemeremintah Daerah (Pemda) dalam rangka implementasi kebijakan pola Siska. Keempat, menganalisis faktorfaktor yang mempengaruhi petani terkait program Siska dalam berinteraksi dengan lembaga sosial lainnya dalam rangka memperjuangkan kepentingan untuk mencapai tujuan produktivitas.

\section{HASIL DAN PEMBAHASAN 1.Aktor dan Tindakan}

Untuk mengidentifikasi para aktor dalam penataan kelembagaan program integarsi sapi-kelapa sawit di desa Rambah Muda diperlukan upaya mengelompokkan para pihak yang bersaing yaitu, para elit yang bersifat mendukung, menolak, dan menerima dengan syarat kebijakan. Dinamika respon para aktor kebijakan tersebut sangat menentukan karakteristik regulasi, lembaga dan sumberdaya percepatan pembangunan ekonomi lokal di Desa Rambah Muda. Pertama, kelompok mendukung yang diwakili Bupati, Dinas peternakan, Badan Perencanaan Pembangunan Daerah (Bappeda), Pemerintah Kecamatan , Pemerintah Desa dan para Penyuluh Pertanian Lapangan (PPL). Para aktor masa reformasi ini, memperebutkan kendali atas kebijakan integrasi sapikelapa sawit dan secara individual atau terlembaga misalnya tidak hanya bertumpu pada asumsi mengejar devisa, melainkan termotivasi juga mengejar kemakmuran masyarakat petani pasca krisis ekonomi seperti yang diungkapkan oleh salah seorang informan.

Tabel.2Aktor Dan Kepentingan Dalam Kebijakan Integrasi Sapi-Kelapa Sawit Di Desa Rambah Muda,Rokan Hulu,2017

\begin{tabular}{|c|l|l|l|}
\hline No & \multicolumn{1}{|c|}{ Aktor } & Kepentingan & Tindakan \\
\hline 1 & $\begin{array}{l}\text { Pemerintah } \\
\text { Kabuapaten }\end{array}$ & $\begin{array}{l}\text { Kesejahteraa } \\
\text { n Petani }\end{array}$ & $\begin{array}{l}\text { Peraturan } \\
\text { Bupati dan } \\
\text { Peraturan } \\
\text { Kadis }\end{array}$ \\
\hline 2 & DPRD & $\begin{array}{l}\text { Penggunaan } \\
\text { Anggaran }\end{array}$ & $\begin{array}{l}\text { Pengawasa } \\
\text { n } \\
\text { Anggaran }\end{array}$ \\
\hline 3 & $\begin{array}{l}\text { Kelompok } \\
\text { Tani }\end{array}$ & $\begin{array}{l}\text { Tambahan } \\
\text { Penghasilan } \\
\text { Anggota }\end{array}$ & $\begin{array}{l}\text { Pemberda } \\
\text { yaan }\end{array}$ \\
\hline 4 & Petani & $\begin{array}{l}\text { Bibit } \\
\text { Sapi,Tambaha }\end{array}$ & $\begin{array}{l}\text { Merawat } \\
\text { Ternak }\end{array}$ \\
\hline
\end{tabular}




\begin{tabular}{|l|l|l|l|}
\hline No & Aktor & Kepentingan & Tindakan \\
\hline & & $\mathrm{n}$ & \\
& & penghasilan, & \\
& & pakan, & \\
& & Pemasaran & \\
& & dan & \\
& & penyuluhan & \\
\hline
\end{tabular}

Sumber: Data Riset, 2017

Menurut Pemda bahwa perkebunan kelapa sawit merupakan potensi daerah yang harus dikelola. Namun potensi perkebunan sawit ini belum sepenuhnya teroptimalkan baik oleh masyarakat maupun pemerintah itu sendiri. Selama ini produk yang mempunyai nilai hanya pada tandan buah, sementara rumput, pelepah, dan daunnya masih menjadi limbah. Oleh karna itu,Pemerintah Kabupaten menerapkan Sistem Integrasi Sapi-Kelapa Sawit untuk mengoptimalkan potensi perkebunan sawit tersebut.

Menurut informan kembali bahwa Sistem Integrasi Sapi-Kelapa Sawit merupakan perpaduan antara manajemen perkebunan kelapa sawit dengan ternak sapi. Perkebunan kelapa sawit dikelola agar hasil samping tanaman terutama pelepah dapat tersedia sepanjang hari untuk pakan sapi yang dimanfaatkan sebagai pengendali rumput/gulma sekitar perkebunan sawit, pengangkut buah sawit dan penghasil kotoran sebagai pupuk organik dan biogas. Bagi Pemerintah Kabupaten, program SISKA merupakan salah satu usaha program percepatan swasembada daging sapi selain sebagai peningkatan Pendapatan Asli Daerah (PAD). Usaha untuk mensejahterakan masyarakat merupakan fokus utama pemerintah yang memanfaatkan potensi lokal.

Kedua, kelompok menerima dengan syarat yang diwakili Dewan Perwakilan Rakyat Daerah (DPRD) Rohul. DPRD sebenarnya mempunyai kekuasaan politik yang sangat besar sebagai representasi dari seluruh rakyat yang diplih melalui Pemilihan Umum (Pemilu) Legislatif. Kedaulatan masyarakat lokal menguat setelah diterapkannya desentralisasibagi aktor yang menerima dengan syarat kebijakan integrasi sapisawit berpendapat bahwa dalam menerapkan program ini diperlukan pengawasan dilakukan oleh DPRD. Menurut informan ini bahwa DPRD melakukan pengawasan pada tahap penganggaran dan distribusi sapi, sementara untuk redistribusi yang dilakukan oleh pemerintah bukan lagi menjadi domain kami. Oleh karena gaduhan ternak ini sifatnya berkelanjutan ataupun bersifat estafet, sebaiknya Dinas Perikanan dan Peternakan menambah tim pengawas lapangan untuk mengawasi ternak pada level paling bawah agar nantinya sapi-sapi yang didistribusikan tidak disalahgunakan .

Ketiga, kelompok yang kontra diwakili tokoh-tokoh lokal. Setelah reformasi para elit lokal ini semakin kritis, terbuka dan tegas dalam menyuarakan tuntutannya kepublik. Para tokoh sebelum reformasi tidak mampu menyampaikan asipirasinya. Setelah reformasi para elit ini menjadi terbuka dan lantang menyampaikan tuntutannya. Kepentingan langsung para tokoh lokal ini sesugguhnya tidaklah jelas seperti yang diungkapkan oleh salah seorang informan. Sementara kepentingan tidak langsung hanyalah bersifat normatif, yakni membentuk opini publik mengenai hak-hak masyarakat lokal yang dimiliki secara turun temurun. Kendatipun demikian, kelompok yang menolak kebijkan integrasi sapi-sawit memiliki 
komitmen yang sangat tinggi kepada daerah misalnya memperjuangkan agar hak-hak ulayat masyarat lokal tidak dilanggar dalam membuka perkebunan.

Jumlah aktor yang menanamkan pengaruh dalam proses kebijakan Siskakelapa sawit di Rambah Muda sangat beragam basis institusionil, kepentingan dan sumberdaya politik yang dimiliki pada masing-masing kelompok. Masingmasing kelompok aktor berupaya agar tujuan dan preferensi politiknya tercapai. Karena itu persaingan antar aktor tidak hanya terjadi antar kelompok misalnya kelompok yang mendukung dengan menolak tetapi terjadi juga dalam kelompok yang sama-sama mendukung atau menolak kebijakan perkebunan kelapa sawit. Untuk itu, tokoh ini mengikuti secara seksama setiap isu pembangunan perkebunan sejak awal di buka hingga dewasa ini.

\section{Kepentingan Aktor}

Dalam penerapan program sistem integrasi sapi-kelapa sawit pada petani pola swadaya, para aktor lokal memiliki sejumlah pertimbanagan ekonomi dan politik. Menurut informan, bahwa para birokrat di lingkungan pemerintah kabupaten Rohul dalam hal ini bersifat mendua terutama sesudah diterapkannya kebijakan desentralisasi dan kebijakan Otda. Secara institusional pada masa Orba lebih banyak mengejar devisa dan produktivitas ternak. Di masa reformasi bergeser selain devisa dan produktivitas juga berupaya mengejar bagaimana program Siska dapat meningkatkan kesejahteraan masyarakat terutama para petani-peternak pola swadaya. Menurut informan birokrat bahwa program Siska merupakan salah satu usaha program percepatan swasembada daging sapi selain sebagai peningkatan Pendapatan Asli Daerah (PAD). Usaha untuk mensejahterakan masyarakat merupakan fokus utama pemerintah yang memanfaatkan potensi lokal dan menata kelembagaan dan melakukan pemberdayaan petani terutama pola swadaya.

Selain itu, para petani swadaya memiliki kepentingan "pasar-input"2 dan "pasar konsumsi"3, sedangkan "pasar output" "sudah sedemikian terbuka. Pasar input petani adalah bibit sapi dan lahan perkebunan. Karena melalui bibit ternak dan (luas) lahan akan diharapkan dapat meningkatkan pendapatan keluarga petani baik yang tergabung atau tidak tergabung dalam kelompok tani. Menurut para petani bahwa program Siska sudah meningkatkan pendapatan keluarga petani meskipun pada batas-batas tertentu masih terbatas. Sebagai gambaran kontribusi integrasi sapikelapa sawit kepada pendapatan ratarata rumah tangga petani adalah sebesar Rp.20.000.000/tahun. Sebelum menerapkan program ini hanya rata-rata Rp.10.000.000/tahun. Kontribusi besaran pendapatan ini tentunya ditentukan oleh jumlah ternak sapi dan harga yang berlaku.

\footnotetext{
${ }^{2}$ Pengertian pasar- input dalam tulisan ini adalah suatu proses pengambilan keputusan oleh para petani terkait sarana produksi pertanian misalnya keputusan dalam hal mendapatkan pupuk,bibit, lahan sebagai bentuk sarana memproduksi kelapa sawit dan sapi.

${ }^{3}$ Yang dimaksud pasar - konsumsi adalah proses pengambilan keputusan oleh para petani berkaitan kebubutahan sandang pangan sehari-hari. Misalnya kebutuhan petani akan beras, gula, garam, kopi dan lain-lain.

${ }^{4}$ Yang dimaksud pasar- output adalah proses pengambilan keputusan oleh petani terkait pemasaran produksi kelapa sawit dan ternak sapi dalam menjalankan usha tani sehari-hari
} 
Tabel.3. Tambahan Penghasilan Bagi Anggota Kelompok Tani di Desa Rambah

\begin{tabular}{|c|c|c|c|}
\hline No & Uraian & Jumlah & $(\%)$ \\
\hline \multirow[t]{4}{*}{1} & $\begin{array}{l}\text { Apakah berternak } \\
\text { menambah } \\
\text { penghasilan? }\end{array}$ & & \\
\hline & a. Ada & 10 & $100 \%$ \\
\hline & b. Tidak & 0 & $0 \%$ \\
\hline & Total & 10 & $100 \%$ \\
\hline \multirow[t]{4}{*}{2} & $\begin{array}{l}\text { Sebelum } \\
\text { berternak,penghasil } \\
\text { an petani ternak }\end{array}$ & & \\
\hline & $\begin{array}{ll}\text { a. } & > \\
& \text { Rp.10.000 } \\
& \text { 000/bulan }\end{array}$ & 10 & $100 \%$ \\
\hline & $\begin{array}{ll}\text { b. } & <\text { Rp. } 10.000 \\
& .000 / \text { bulan }\end{array}$ & 0 & $0 \%$ \\
\hline & Total & 10 & $100 \%$ \\
\hline \multirow[t]{5}{*}{3} & $\begin{array}{l}\text { Setelah berternak } \\
\text { penghasilan petani } \\
\text { ternak }\end{array}$ & & \\
\hline & a. $>$ & & \\
\hline & $\begin{array}{l}\text { Rp.20.000. } \\
\text { 000/bulan }\end{array}$ & 10 & $100 \%$ \\
\hline & $\begin{array}{ll}\text { b. } \quad< \\
\\
\text { Rp.20.000. } \\
\text { 000/bulan }\end{array}$ & 0 & $0 \%$ \\
\hline & Total & 10 & $100 \%$ \\
\hline
\end{tabular}

Sumber:Data Riset , 2017

Menurut informan, sebelum berusaha ternak yang diintegrasikan dengan kelapa sawit pendapatnya hanya bergantung pada hasil produksi perkebunan kelapa sawit. Para petani pola swadaya rata-rata memiliki luas kebun kepala sawit sekitar 2- 3 hektar/ KK yang terluas 8 hektar dengan pendapatan Rp.2.000.000/bulan. Dalam kondisi perekonomian keluarga seperti ini, tertutup kemungkinan bagi para petani utnuk menabung. Dalam memenuhi kebutuhan keluarga yang mendesak misalnya keperluan anak sekolah, kebutuhan berobat biasanya para petani berhutang kepada para "orang berpunya". Namun dengan usaha program SISKA para petani dapat memenuhi kebutuhan mendesak dengan cara menjual ternak atau menabung hasil penjualan ternak sapi sedemikian rupa terutama pada waktu hari-hari besar hari raya. Selanjutnya, responden dari kelompok tani menyatakan bahwa berternak sapi ternyata dapat membuka kesempatan kerja, 90\% responden menyatakan kurang dari 5 orang/ha dapat menampung tenaga kerja.

Tabel4. Kepemilikan Lahan DanPemasaran Produksi Kelompok Tani Desa Rambah Muda

\begin{tabular}{cccc}
\hline No & URAIAN & JUMLAH & $\begin{array}{c}\text { PERSENTASE } \\
(\%)\end{array}$ \\
\hline \multirow{2}{*}{1} & Kepemiikkan : & & \\
\cline { 2 - 4 } & a. Milik Sendiri & 0 & $0 \%$ \\
\cline { 2 - 4 } & b. Sewa & 0 & $0 \%$ \\
\cline { 2 - 4 } & c. Gaduhan & 0 & $0 \%$ \\
\cline { 2 - 4 } & d. Tidak ada & 10 & $100 \%$ \\
\hline \multirow{3}{*}{ Total } & 10 & $100 \%$ \\
\cline { 2 - 4 } & Apakah pemasaran produksi ternak ? \\
\cline { 2 - 4 } & a. Mudah & 10 & $100 \%$ \\
\cline { 2 - 4 } & b. Kurang & 0 & $0 \%$ \\
\hline c. & Tidak mudah & 0 & $0 \%$ \\
\hline & Total & 10 & $100 \%$ \\
\hline
\end{tabular}

Sumber:Data Riset, 2017

Dengan penjelasan diatas, informan juga ingin mengatakan bahwa dari data diatas jelaslah mengapa Pemerintah Daerah di Rokan Hulu khususnya dalam era desentralisasi dan Otda ini memiliki komitmen untuk mengembangkan program integrasi sapi-kelapa sawit dengan tujuan mewujudkan kesejahteraan masyarakat lokal. Untuk menegaskan hal itu misalnya informan di Desa Rambah Muda, Rokan Hulu memberi contoh alokasi anggaran untuk program "gaduhan ternak" melalui dana APBD Kabupaten Rokan Hulu tahun 2012-2015.

Tabel 6. Target, Anggaran, Realisasi Distribusi Bibit Sapi Tahun 2012-2015

\begin{tabular}{ccccc} 
No & Tahun & $\begin{array}{c}\text { Target } \\
\text { (ekor) }\end{array}$ & Anggaran (Rp) & Realisasi \\
\hline 1 & 2012 & 921 & 6.822 .509 .000 & 921 \\
\hline 2 & 2013 & 600 & 4.508 .502 .000 & 667 \\
\hline 3 & 2014 & 700 & 5.410 .562 .000 & 0 \\
\hline 4 & 2015 & 800 & 6.492 .674 .000 & 0 \\
\hline
\end{tabular}

Sumber:Data Riset, 2017 
Pengelolaan program "gaduhan ternak" di Kabupaten Rokan Hulu merupakan kewenangan dari Dinas Perikanan dan Peternakan. Proses dimulai dengan membentuk Peraturan Bupati Rokan Hulu Nomor 21 Tahun 2012 Tentang Pola Pengembalian Gaduhan Ternak.Dalam penerapannya Dinas Perikanan dan Peternakan Kabupaten Rokan Hulu sebagai leading sector. Untuk mengimplementasi Peraturan Bupati Rokan Hulu, Dinas Perikanan dan Peternakan Kabupaten Rokan Hulu membuat SOP (Standart Operational Procedur) dari gaduhan ternak tersebut dengan mengeluarkan Keputusan Kepala Dinas Perikanan dan Peternakan Kabupaten Rokan Hulu No. Kpts524.1/Diskannak/Tahun2012

Tentang Pola Pengembalian Gaduhan Sapi di Kabupaten Rokan Hulu yang merupakan turunan dari Peraturan Bupati Rokan Hulu Nomor 21 Tahun 2012 Tentang Pola Pengembalian Gaduhan Ternak di Kabupaten Rokan Hulu. Menurut informan bahwa prosesnya dimulaidenganmenyusun data-data kelompok tani yang akan menerima bantuan bibit sapi dengan meyesuaikan kelompok tani dengan jumlah bibit sapi yang akan didistribusi-kan kedalam kegiatan atau program Satuan Kerja Perangkat Daerah(SKPD) Dinas Perikanan dan Peternakan, karena pedoman kita ada pada renstra tersebut. Kemudian akan diserahkan kepada Bappeda untuk dibuatkan anggarannya dan disahkan dalam APBD. Begitu seterusnya pada perencanaan gaduhan ini di tahun-tahun berikutnya

Masih menurut informan bahwa implementasi program integrasi sapikelapa sawit tidak lepas dari kelemahan misalnya dalam mempersiapkan program pembinaan petani swadaya.Petugas Lapangan Pembina Ternak Bibit Kabupaten Rokan Hulu ini diangkat melalui Surat Keputusan Kepala Dinas Perikanan dan Peternakan Kabupaten Rokan Hulu No.821.2/KP/220/03. 2015 sebanyak 26 orang yang tersebar di 16 kecamatan. Hali ini diakui oleh Organisasi Perangkat Daerah (OPD). Menurut informan iniUntuk urusan teknis di dinas kita tidak mempunyai masalah, tetapi untuk petugas lapangan yang mendampingi peternak atau penggaduh ternak ini masih kurang. Karena dalam 16 Kecamatan tersebut ada petugas lapangan yang mempunyai tugas mengawasi dan membina lebih dari satu kecamatan yang jaraknya lumayan jauh dan juga kelompok yang diawasi juga banyak sehingga kadang mereka juga kewalahan sehingga tidak terkontrol secara keseluruhan. Untuk mempermudah pekerjaan petugas lapangan ini setidaknya dalam satu desa tersebut dibina oleh satu orang petugas lapangan.

\section{Sumberdaya Petani}

Implementasi kebijakan integrasi sapi-kelapa sawit di era reformasi dan Otda selain diwarnai karakteritik para aktor kebijakan, sumber daya petani mempunyai peran yang penting dalam variabel lingkungan kebijakan. Para petani memiliki kepentingan yang beragam, latar pendidikan yang bermacam-macam.Di sebelum reformasi, keragaman latar sosial ini terpendam.Sesudah reformasi, kondisi ini diungkap-kan petani semakin terbuka dan dinamik.Dalam kondisi seperti ini. Pemda harus tanggap untuk mempertimbangkan ke-pentingan petani 
dalam proses kebijakan. Potensi keragaman basis sosial ini jika tidak diorganisasikan dalam batas-batas tertentu dapat menjadi sumber ketegangan sosial.Oleh karena itu, upaya mendemokrasikan politik lokal menjadi keharusan bersama dalam kebijakan integrasi sapi-kelapa sawit di Rokan Hulu.

Para petani adalah pihak yang rasional, aktor ini berupaya memaksimalkan kepentingannya dalam berternak sapi Dalam rangka mencapai tujuannya tersebut, para petani ini bersaing menanamkan pengaruhnya dalam proses kebijakan dan kehidupan sosial kemasyarakatan sehari-hari. Keberhasilan dalam mencapai tujuannya tersebut ditentukan antara lain oleh sumberdaya yang dimilikinya misalnya tingkat pendidikan, pengalaman dalam bertani, lahan, sarana produksi, konsumsi keluarga dan pemasaran. Kondisi primer ini berdampak kepada tinggi rendahnya kesadaran petani dalam mendukung kebijakan system integrasi sapi-kelapa sawit. Tingkat pendidikan dan usia para petani dapat dilihat dari tabel berikut ini:

Tabel.6.Tingkat Pendidikan dan Usia Petani di Desa Rambah Muda

\begin{tabular}{|c|c|c|c|}
\hline No & URAIAN & JUMLAH & $\begin{array}{c}\text { PERSENTASE } \\
(\%)\end{array}$ \\
\hline \multirow[t]{7}{*}{1} & Pendidikan & & \\
\hline & $\begin{array}{l}\text { a. Tidak Tamat } \\
\text { SD }\end{array}$ & 1 & $2,5 \%$ \\
\hline & b. Tamat SD & 26 & $65 \%$ \\
\hline & c. Tamat SLTP & 13 & $32,5 \%$ \\
\hline & d. Tamat SLTA & 0 & $0 \%$ \\
\hline & e. Tamat Diploma & 0 & $0 \%$ \\
\hline & Jumlah & 40 & $100 \%$ \\
\hline \multirow[t]{5}{*}{2} & Umur (tahun) & & \\
\hline & a. $<14$ & 0 & $0 \%$ \\
\hline & b. $15-55$ & 39 & $97,5 \%$ \\
\hline & c. $>55$ & 1 & $2.5 \%$ \\
\hline & Jumlah & 40 & $100 \%$ \\
\hline
\end{tabular}

Sumber: Data Riset, 2017

Dari data tabel diatas nampak bahwa rata-rata tingkat pendidikan petani yang terkait program integrasi sapi-kelapa sawit di Desa Rambah Muda tamat SD (65\%) dan dalam usia produkstif rata-rata 15-55 tahun. Kondisi sosial ini memang bersifat relatif dalam mempengaruhi perilaku petani.Namun apabila dilihat dari lama waktu berusaha ternak,para petani umum relatif baru yaitu <3 tahun. Hal inilah yang menjelaskan mengapa para petani secara struktural bersikap kurang berpartisipasi penuh dalam program integrasi sapikelapa sawit yang diterapkan pemerintah ,meskipun para petani mengakui manfaatnya. Misalnya sebagai contoh partisipasi petani dalam kebijakan Sapi Gaduhan yang diformulasikan Pemda Rokan Hulu melalui Peraturan Bupati Rokan Hulu No. 21 Tahun 2012 Secara rinci kebijakan gaduhan sapi ini telah mendistribuasikan tahun 2012 sebanyak 921 ekor, 2013 sebanyak 600 ekor, 2014 sebanyak 700 ekor, dan 2015 sebanyak 800 ekor. Akan tetapi dalam pengembalian petani mengalami persoalan yaitu pada tahun 2015 dengan persentase $13,9 \%$ sedangkan pada tahun 2016 dengan 4,2\% (Yatma, 2017)

Tabel.7. Lama Petani Berusaha Ternak Dan Ketersediaan Sarana Produksi Di Desa Rambah Muda

\begin{tabular}{|c|c|c|c|}
\hline No & URAIAN & JUMLAH & $\begin{array}{c}\text { PERSENTASE } \\
(\%)\end{array}$ \\
\hline \multirow[t]{5}{*}{1} & \multicolumn{3}{|c|}{ Lama Petani berusaha Ternak: } \\
\hline & a. $<3$ Tahun & 8 & $80 \%$ \\
\hline & b. > 3 Tahun & 2 & $20 \%$ \\
\hline & c. 10 Tahun & 0 & $0 \%$ \\
\hline & Jumlah & 10 & $100 \%$ \\
\hline \multirow[t]{4}{*}{2} & \multicolumn{3}{|c|}{ Apakah bergabung dengan kelompok tani : } \\
\hline & a. Bergabung & 21 & $52,5 \%$ \\
\hline & $\begin{array}{ll}\text { b. } & \text { Tidak } \\
& \text { Bergabung }\end{array}$ & 19 & $47,5 \%$ \\
\hline & Jumlah & 40 & $100 \%$ \\
\hline \multirow[t]{4}{*}{3} & \multicolumn{3}{|c|}{ Ketrsediaan Sarana Produksi : } \\
\hline & a. Tersedia & 8 & $80 \%$ \\
\hline & $\begin{array}{ll}\text { b. } & \text { Kurang } \\
& \text { Tersedia } \\
\end{array}$ & 2 & $20 \%$ \\
\hline & c. Tidak Tersedia & $\mathbf{0}$ & $0 \%$ \\
\hline
\end{tabular}




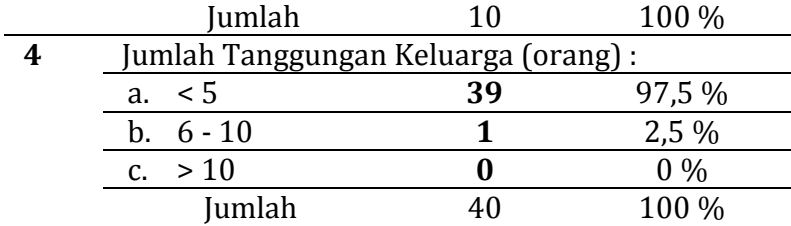

Sumber: Data Riset, 2017

Pertanyaan selanjutnya mangapa para petani dalam batas-batas tertentu masih tetap bertahan bersikap mendukung program integrasi sapi-kelapa sawit, meskipun tingkat pendidikan dan keterampilan serta pengalaman tergabung dalam kelompok tani terbatas. Fakta ini terjadi karena informan menilai sarana produksi misalnya bibit, pakan ternakn dan lahan perkebunan masih tersedia. Selain itu, jumlah anggota keluarga yang ditanggung petani ternyata menjadi alasan rasional seperti yang dijawab responden dalam wawancara. Menurut informan (baik yang tergabung dalamkelompok tani atau tidak bergabung) bahwa dalam memenuhi kebutuhan keluarga yang mendesak, para petani sering kali bergantung dengan produksi ternak yang ada. Hal ini dimungkinkankan karena dukungan akses pemasaran yang terbuka.

Secara Kelembagaan, sepanjang yang dapat diamati bahwa analisis dukungan terhadap kebijakan integrasi sapi-kelapa sawit diatas akan dapat beretahan apabila kondisi sosial petani tersebut diimbangani oleh adanya intervensi pemerintah (Daerah) dalam bentuk pembinaan secara terlembaga artinya ada dukungan regulasi (tidak hanya yang mengatur anggaran), pembagian kerja dan koordinasi antar lembaga terkait dan fokus kegiatan kepada pemberdayaan petani dalam konteks program. Hingga tahun 2017, program pembinaan relatif sudah berjalan tetapi hanya dilakukan oleh PPL dengan frekunesi 2 kali setahun melalui pendekatan kelompok tani. Berdasarkan data dari kelompok tani mengenai pelaksanaan program pembinaan oleh PPL pertanian dapat dilihat dari tabel berikut ini:

Tabel 8. Pembinaan Kelompok Tani Desa Rambah Muda

\begin{tabular}{|c|c|c|c|}
\hline No & Uraian & Jumlah & $\begin{array}{c}\text { Persentase } \\
(\%)\end{array}$ \\
\hline \multirow[t]{4}{*}{1} & \multicolumn{3}{|l|}{ Apakah ada pembinaan : } \\
\hline & a. Ada & 10 & $100 \%$ \\
\hline & b. Tidak & 0 & $0 \%$ \\
\hline & Total & 10 & $100 \%$ \\
\hline \multirow[t]{5}{*}{2} & \multicolumn{3}{|c|}{ Siapa yang melakukan pembinaan : } \\
\hline & $\begin{array}{ll}\text { a. } & \text { Penyuluhan } \\
& \text { Pertanian } \\
& \text { Lapangan (PPL) }\end{array}$ & 10 & $100 \%$ \\
\hline & $\begin{array}{ll}\text { b. } & \text { Lembaga Sosial } \\
& \text { Masyarakat (LSM) }\end{array}$ & 0 & $0 \%$ \\
\hline & c. Perusahaan & 0 & $0 \%$ \\
\hline & Total & 10 & $100 \%$ \\
\hline \multirow[t]{6}{*}{3} & \multicolumn{3}{|c|}{ Bentuk Pembinaan/Penyuluhan : } \\
\hline & $\begin{array}{ll}\text { a. } & \text { Bina Manusia } \\
\text { (Pengembang } \\
\text { Kapasitas Petani) }\end{array}$ & 8 & $80 \%$ \\
\hline & $\begin{array}{ll}\text { b. } & \text { Bina Usaha } \\
\text { (Pembentukan } \\
\text { Badan Usaha, } \\
\text { Manajemenm } \\
\text { Sistem Informasi) }\end{array}$ & 2 & $20 \%$ \\
\hline & $\begin{array}{ll}\text { c. } & \text { Bina Lingkungan } \\
& \text { (Pelestarian } \\
& \text { Lingkungan) } \\
\end{array}$ & 0 & $0 \%$ \\
\hline & $\begin{array}{ll}\text { d. } & \text { Bina Kelembagaan } \\
& \text { (Sosialisasi } \\
& \text { Peraturan } \\
& \text { Perundangan) } \\
\end{array}$ & 0 & $0 \%$ \\
\hline & Total & 10 & $100 \%$ \\
\hline \multirow[t]{4}{*}{4} & \multicolumn{3}{|c|}{ Waktu Pembinaan Dilakukan : } \\
\hline & a. $>2$ Kali Setahun & 8 & $80 \%$ \\
\hline & b. $<2$ Kali Setahun & 2 & $20 \%$ \\
\hline & Total & 10 & $100 \%$ \\
\hline
\end{tabular}

Sumber:Data Riset ,2017

\section{Stretegi Pemberdayaan}

Strategi pemberdayaan petani era Otda berbeda dengan sebelum Otda.Jika sebelum Otda, pemberdayaan petani terfokus pada lembaga-lembaga petani di desa. Sesuadah Otda pemberdayaan petani hendaknya mengarah kepada kepentingan petani yaitu, bagaimana membangun struktur yang dapat 
menjamin mengatasi masalah Pasar Input, Pasar Output dan Pasar Konsumsi para petani. Proses pemberdayaan itu menekankan langkah membangun struktur penopang pemberdayaan. Tujuannya adalah agar petani memiliki akses (berdaya) dalam proses kebijakan di tingkat lokal. Proses pemberdayaan ini dimulai dari langkah pertama, Pemkab melakukan komunikasi terhadap DPRD. Proses komunikasi ini dimaksudkan untuk memperkuat identifikasi terhadap berbagai kepentingan petani misalnya pupuk, bibit sapi sarana dan prasaran pendukung lainnya. Legitimasi DPRD penting dalam merancang dan mengimplementasikan regulasi pemberdayaan.Materi yang harus diketahui oleh para politisi adalah isu-isu strategis baik yang berdampak lokal, nasional, dan global.Isu-isu ini diperbincangkan dan diperdebatkan di tengah-tengah masyarakat.Pemetaan terhadap isu-isu strategis menjadi bahan untuk mengidentifikasi kebijakan.

Langkah kedua, sosialisasi bagi pelaku Bisnis (perusahaan).Tujuannya adalah agar para petani mendapatkan akses/jaringan pemasaran lebih luas dalam berusaha.Pada umumnya, program-program pemberdayaan perusahaan perkebunan lebih duluan dikembangkan di tengah-tengah masyarakat.Sosialisasi yang disampaikan ini dimaksudkan untuk memperkuat identifikasi terhadap berbagai kepentingan petani dalam pemberdayaan. Sosialisasi kepada para pelaku bisnis mengacu pada dokumen yang sudah disepakati dan menjadi komitmen bersama yaitu visi dan misi pemerintah Daerah yang tertuang dalam Rencana Pembangunan Jangka Menengah Daerah
(RPJMD) dan Rencana Pembangunan Jangka Panjang Daerah (RPJPD).RPJMD tertuang dalam Kebijakan, program, kegiatan dalam rentang waktu lima tahun. RENSTRA Dinas peternakan.Langkah kertiga, Sosialisasi dan Diskusi publik Terhadap Satuan Kerja Perangkat Daerah (SKPD).Sosialisasi SKPD ini dimaksudkan untuk memperkuat identifikasi terhadap unsurunsur kepentingan petani meliputi; bibit sapi,pemasaran dan konsumsi petani. Setiap masalah itu diidentifikasi isu kebijakan (hal-hal yang dipandang sebagai kebutuhan petani), masalah kebijakan dan formula kebijakan itu sendiri. Substansi materinya adalah: Pertama; materi yang harus diketahui oleh para satuan kerja adalah isu-isu strategis baik yang berdampak lokal, nasional, dan global. Isu-isu ini diperbincangkan dan diperdebatkan di tengah-tengah masyarakat.Pemetaan terhadap isu-isu strategis menjadi bahan untuk mengidentifikasi masalah-masalah petani. Adapun cara kerja yang dipakai dalam diskusi adalah tatap muka, wawancara, Focus Group Discusion, diskusi kelompok, dilanjutkan dengan ceramah. Metode yang paling tepat untuk para SKPD adalah metode tukar pengalaman, FGD, seminar dan loka karya. Foto, gambar, animasi, brosur, materi yang sudah dimasukan dalam komputer, LCD dan Listrik, konsultasi publik (ditempat tertutup/terbuka), materi yang telah ditulis sebagai bahan diskusi,dan tabelmatrik berisikan pertanyaan penuntun.

Langkah ketiga, sosialisasi dan diskusi kepada Para Camat, Kepala Desa dan PPL.Bahan sosialisasi ini dimasudkan untuk memperkuat identifikasi terhadap 
upaya mengatasi berbagai kepentingan petani yang sudah disepakati dengan DPRD dan SKPD. Struktur pemerintah Desa dan PPL diharapkan dapat mendukung kegiatan-kegiatan pemberdayaan petani. Oleh karena itu kebijakan, program, kegiatandan pendanaan dan standart operational procedur (SOP) pemberdayaan dapat tersosialisasikan dengan baik di tingkat PPL. Secara teknis struktur inilah yang menjadi ujung tombak berbagai kegiatan pemberdayaan bagi petani. PPL diharapkan tidak lagi bekerja sendiri dalam melakukan kegiatan penyuluhan dan pembinaan kepada petani. Pada akhirnya para petani benar-benar berdaya dalam membuat keputusan dan mendapatkan akses dalam proses kebijakan di Daerah.,

\section{SIMPULAN DAN SARAN}

\section{Simpulan}

Dengan menggunakan pertanyaan penelitian yang dirumuskan dalam bagian terdahulu sebagai penuntun, penulis dapat menarik kesimpulan riset ini sebagai berikut Penataan pemberdayaan petani tidak dimulai dari lembaganya melainkan dari petani sesuai dengan konteks yang dihadapi. Sepanjang yang dapat diamati pemberdayaan petani swadaya dilakukan seolah-olah hanya menjadi tanggung jawab Dinas Pertanian dan Peternakan. Lembaga-lembaga pemerintah dan non pemerintah belum terintegrasi sedemikian rupa. Strategi pemberdayaan petani pola swadaya Desa Rambah Muda dapat dimulai dengan membangun struktur penopang kelembagaan petani yaitu regulasi pemerintah yang dapat mengintegrasikan lembagta-lembaga dan menjamin proses kebijakan dan pendanaan program pemberdayaan. Program ini diarahkan kepada tiga hal: aturan main lokal, lembaga lembaga sosial petani dan peningkatan kapasitas sumberdaya petani, ilmu pengetahuan dan teknologi sedemikian rupa secara berkelanjutan. Beberapa langkah inilah diharapkan akan membangun tindakan kolektif para aktor dalam mendesentralisasikan kuasa kepada petani dalam membuka akses ke proses pengambilan keputusan di tingkat lokal.

\section{Saran}

Paling tidak ada dua hal yang menarik dari kontemplasi hasil studi ini yang dapat dijadikan inspirasi bagi peneliti berikutnya. Pertama, ide riset dasar. Politik pemberdayaan petani di Rambah Muda terkait isu kebijakan Siska menghasilkan pergulatan politik-ekonomi yang dinamis. Bagaimana konsepsi kekuasaan petani untuk bertahan dalam situasi konflik itu? Menjadi riset selanjutnya yang menarik dilakukan. Kedua, ide riset terapan. Strategi memperkuat posisi Kepala Desa sebagai manajer pasar-input dan konsumsi dipandang riset politik yang jarang dilakukan paling tidak di Riau.

Berdasarkan beberapa temuan riset diatas memunculkan implikasi sifat politik lokal yang dinamis dan arah perkembangannyaternyata menghasilkan kebijakan-kebijakan publik yang bersifat komplementer. Oleh karena itu, jalan yang mungkin ditempuh Pemerintah (Daerah) adalah mendialogkan demokrasi sejak awal bersama masyarakat petani.

\section{DAFTAR PUSTAKA}


Anwar, Khairul. 2014. Sinergi dan Strategi Kebijakan Desentralisasi Lintas Kementerian: Studi kasus Kebijakan Kelapa Sawit K2-I di Riau. Jakarta: DP2M Dikti.

Casson, Anne .2000.The Hesitant Boom: Indonesia's Oil Palm Subsector in an Era of Economic Crisis and Political Change, http://www.Occasional paper no.29.

Daryanto, Arief. 2007. Peningkatan Daya Saing Industri Perternakan. Jakarta: PT.Permata wacana Lestari.Trobos

Eko, Sutoro. 2013. Daerah Inklusif: Pembangunan, Demokrasi Lokal dan Kesejahteraan. Yogyakarta: IRE

Elizabeth, Roosganda.2007.Penguatan Dan pemberdayaan Kelembagaan Petani Mendukung Pengembangan Agribisnis kedelai, prosiding Seminar Seminar nasional Dinamika Pembangunan Pertanian Dan Perdesaan:Mencari alternative Arah Pengembangan Ekonomi rakyat.Pusat Analisis Sosial ekonomi Dan Kebijakan Pertanian Badan Penelitian Dan Pengembangan Pertanian Departemen Pertanian.

Frieden, Jeffry (etl) . 2000. The Method of Analysis: Modern Political Economy.dalam Modern Political Economy Theory and Latin and America Policy. Princeton,NJ:University Press.

Isril. 2015. Konflik Pertanahan Berbasis Perkebunan Di daerah Aliran Sungai, Kasus DAS Siak, 2004-2014. Laporan Penelitian. Universitas Riau
: Lembaga Penelitian dan Pengabdian Kepada Masyarakat.

Mubyarto .1995. Riau Menatap masa Depan . Hasil Penelitian. Yogyakarta: P3PK-UGM.

Nano, Obed Haba. 2011.Dampak Kelembagaan bagi Hasil Terhadap Kinerja Usaha Penggemukan Hasil Sapi Potong di Kabupaten Kupang. Jurnal Sosio humaniora, Maret 2011, Vol 13.No.1: 20-38

Nirwugo, Joga. 2013. Kota Hijau (GreenCity), Jakarta: Gramedia.

Sulistyani, Ambar Teguh. 2017.Kemitraan Dan Model-Model Pemberdayaan. Gava Media:Yogyakarta

Tohari, Amin. 2013. Keluar Dari Demokrasi Populer:Dinamika Demokrasi Lokal dan Distribusi Sumber Daya. Yogyakarta: Polgov

Rozaki, Abdur. 2016. Memberdayakan Desa di Indonesia melalui Pendampingan Asimetris. Analisis CSIS, Kuartal Ketiga.Vol 45.No.3: 251-264.

Pranadji, Tri. 2003. Penajaman Analisis Kelmbagaan Dalam Perspektif Penelitian Sosiologi Pertanian Dan Pedesaan.Jurnal Forum Agro Ekonomi. Juli 2003,Vol 21,No.1:1225.

\begin{tabular}{|c|c|}
\hline $\begin{array}{l}\text { _2003.Dianogsa } \\
\text { kelembagaan }\end{array}$ & $\begin{array}{r}\text { kerap } \\
\text { perekono }\end{array}$ \\
\hline Pedesaan.Jurnal & Forum \\
\hline $\begin{array}{l}\text { Ekonomi.Desember } \\
\text { No.2: } 128-142\end{array}$ & 2003.Vol \\
\hline
\end{tabular}




\section{Jurnal Ilmu Pemerintahan, 2 (2), Oktober 2017 - 118}

Khairul Anwar, dan Meizy Haryanto

Yatma,As.Rama Ady. 2017.Manajemen

Pemerintahan

DaerahDalamGaduhan

TernakDiKabupaten Rokan Hulu

Tahun 2012-2016. Skripsi. Jurusan

Ilmu Pemerintahan Fakultas

Ilmu Sosial Dan Ilmu Politik Universitas Riau.

Syahza, Almasdi dan Henny Indrawati. 2010. Pemberdayaan Koperasi Berbasis Agribisnis DiDaerah Pedesaan. Jurnal Sosiohumaniora. November 2010.Vol 12 No.3 : 207220

\section{Peraturan Perundangan:}

Peraturan Menteri Lingkungan Hidup, Republik Indonesia, Nomor 27 tahun 2009 tentang "Pedoman Pelaksanaan Kajian Lingkungan Hidup Strategis (KLHS)", Kementerian LH, Jakarta.

Undang-Undang Nomor 23 Tahun 2014 Tentang Pemerintahan Daerah

Peraturan Bupati Rokan Hulu Nomor 45 Tahun 2012 Tentang Rencana Aksi Daerah Percepatan Pencapaian Target Millenium Development Goals Tahun 2012-2015

Peraturan Bupati Rokan Hulu Nomor 21 Tahun 2012 Tentang Pola
Pengembalian Gaduhan Ternak di Kabupaten Rokan Hulu

Peraturan Bupati Rokan Hulu Nomor 71 Tahun 2011 Tentang Uraian Tugas dan dan Tata Kerja Jabatan Struktural Pada Dinas Perikanan dan Peternakan Kabupaten Rokan Hulu.

\section{PROFIL SINGKAT}

Khairul Anwar, lahir di Siak Sri Indrapura 7 Juli 1965. Menyelesaikan pendidikan S1 Ilmu Pemerintahan-Unri, tahun 1984-1989; S2 Ilmu Politik-UGM, tahun 1995-1998; S3 Ilmu Politik-UGM, tahun 2005-2009. Dosen Jurusan Ilmu Pemerintahan dan Pascasarjana Ilmu Politik Unri. Anggota Dewan Pakar dan Peneliti LPPM- Unri 20013-2018 dan Anggota Tim Pokja IDI Riau 2010-2017

Meyzi Hariyanto, lahir di Kapar 31 Agustus 1975. Pendidikan S1 Administrasi Bisnis-Unri tahun 19931997; S2 Ilmu Administrasi Bisnis Unbraw tahun 1999-2001; S3 Ilmu Administrasi dan Bisnis Unbraw tahun 2003-2008. Dosen Ilmu Administrasi dan Pascarjana Unri. Ketua Prodi Ilmu Administrasi Pascasarjana Unri 200132017 , aktif sebagai peneliti LPPM-Unri 2013-2017 dan Anggota Tim BAN-PT Dikti tahun 2010-2017. 